\title{
Lise Son Sınıf Öğrencileri Sağlıklı Yaşam Biçimi Davranışlarına Sahipler mi?*
}

\author{
Do Senior High School Students Have Health-Promoting Lifestyles?
}

\author{
Aylin AKTAŞ ÖZAKGÜL**, Türkinaz ATABEK AŞTI***, Merve ATAÇ****, Kübra MERCAN*****
}

İletişim/Correspondence: Merve ATAÇ Adres/Address: Banvit A.Ş. Ömerli mh, Ömerli sok. No: 208 Bandırma/Balıkesir Tel: 02667338600 Fax: 02667338616 E-mail: merve.atac@hotmail.com.tr

\begin{abstract}
$\ddot{O} Z$
Adolesan dönem, sağlıkl yaşam biçimi davranışlarının kazanılması ve bu davranışların yetişkinlikte devam ettirilmesi açısından önemli bir yaşam dönemdir. Bu araştırma, lise son sını ögrrencilerinin sağllkll yaşam biçimi davranışlarını ve etkileyen etmenlerin incelenmesi amacıyla tanımlayıcı ve ilişsi arayıcı türde gerçekleştirildi. Araştırmanın örneklemini, bir ortaögretim kurumunda 2010-2011 eğitim-öğretim yll 2. döneminde eğitim-öğrenim gören 160 ögrenci oluşturdu. Verilerin toplanmasında Bilgi Formu ve Sağlıklı Yaşam Biçimi Davranışları Ölçeği-II kullanıld. Bu çalışmada lise son sinıf ögrencilerinin sağllkl yaşam biçimi davranışlarının orta düzeyde olduğu, ölçeğin fiziksel aktivite ve sağllk sorumluluğu alt boyutlarından düşük puan aldıkları belirlendi. Kız öğrencilerin sağllk sorumluluğu, beslenme ve kişilerarası ilişki davranışlarının erkek öğrencilere göre, erkek öğrencilerin ise fiziksel aktivite davranışlarının kiz öğrencilere göre daha iyi olduğu saptandı. Yaşamını ilçede geçiren, ailelerinin geliri yüksek olan, yakın çevrelerinde sağllk personeli olan öğrencilerin sağllklı yaşam biçimi davranışları gösterdiği belirlendi. Bu araştırmadaki lise öğrencilerinin sağllklı yaşam biçimi davranışlarının yeterli düzeyde olmadı̆̆ı saptanmıştır. Bu sonuç, lise son sınıf öğrencilerine yönelik eğitim programlarının planlanması ve uygulamaya geçirilmesinin gerekliliğini ortaya koymaktadır.
\end{abstract}

Anahtar Kelimeler: Lise, öğrenciler, Sağlıklı Yaşam Biçimi Davranışları Ölçeği.

\section{ABSTRACT}

Adolescence is an important time to acquire a health-promoting lifestyle so that it can be maintained in adulthood. This is a descriptive and correlational study. The aim of the study is to analyze the health-promoting lifestyles of senior high school students and the factors that affect this lifestyle. The study sample included 160 high school students. It was conducted in the spring semester of the 2011 academic year. The study data was collected using an information form and the Health-promoting Lifestyle Scale 2. The study found that the senior high school students had a moderately healthpromoting lifestyle. They obtained low scores on the physical activity and health responsibility subdimensions of the scale. The female students had better health responsibility, nutrition and interpersonal relationships than the male students, while the male students were better in physical activities than the female students. The study also found that the students who lived in city, came from a high-income family and had health professionals in their immediate environment had more health-promoting lifestyles. According to the study results, the senior high school students did not have sufficiently healthpromoting lifestyles. This indicates that training programs addressed to senior high school students should be planned and implemented.

Keywords: High school, students, Health Promotion Life Style Profile.

\footnotetext{
*10. Ulusal-Uluslararası Katılımlı Hemşirelik Öğrencileri Kongresi’nde poster bildiri olarak sunulmuştur (28-30 Nisan 2011, Gaziantep), **Yrd. Doç. Dr. Istanbul Üniversitesi Florence Nightingale Hemşirelik Fakültesi, ***Prof. Dr. Bezmialem Vakıf Üniversitesi Sağllk Bilimleri Fakültesi ****IŞ yeri hemşiresi BANVIT A.Ş., *****Hemşire Paşabahçe Devlet Hastanesi
}

Yazının gönderilme tarihi: 18.05.2015

Yazının basım için kabul tarihi: 29.01.2016 


\section{GíRiş}

Dünya Sağlık Örgütü (DSÖ) verilerine göre dünya çapında 2008 yılında meydana gelen 57 milyon ölümden 36 milyonunun; kardiyovasküler hastalıklar, kanserler, diyabet ve kronik akciğer hastalıklarını içeren bulaşıcı olmayan hastalıklardan kaynaklandığı bildirilmektedir. Bulaşıcı olmayan hastalıklara bağlı ölümlerin 2010 ve 2020 yılları arasında ise bütün dünyada $\% 15$ oranında artacağ birlikte bulaşıcı olmayan hastalıkların büyük bir kısmının, tütün kullanımı, fiziksel aktivite eksikliği, alkolün zararlı kullanımı ve sağlısız beslenme gibi davranışsal risk faktörlerinin azaltılmasıyla önlenebileceği belirtilmektedir. Bu risk faktörlerinin ise toplum içinde yaygın biçimde olduğu ve çoğunlukla erken yaşta başlayarak erişkinlik boyunca da sürdüğü belirtilmektedir (DSÖ Kütüphanesi Kataloğu 2011).

Adölesan ve genç yetişkinlik döneminde belirlenen sağlık davranışlarının; kalıcı sağlık davranışları oluşturma ve hastalık görülmesi/ yaşam kalitesi üzerinde önemli bir etkisi vardır. Adolesan dönem, sağlıklı yaşam biçimi davranışlarının kazanıldığ 1 ve alışkanlığa dönüştürülmesi açısından önemli bir dönemdir (Von Ah, Ebert, Ngamvitroj, Park ve Kang 2004). Davranış değişikliği kararının sürdürülmesinde ise, karara yönelik davranış değişikliğine inanmanın önemi ortaya çıkmaktadır (Alıcı ve Sarıkaya 2009). Ne yazık ki adölesanlar ile ilgili yapılan çalışmalarda alkol kullanımı, sigara kullanımı, fiziksel hareketsizlik ve sağlıksız beslenme alışkanlıkları, aşırı güneşe maruz kalma gibi çeşitli riskli sağlık davranışlarının adölesanlar tarafından önemsenmediği belirtilmektedir (Von Ah ve ark. 2004).

Adölesan dönemindeki öğrencilerin sağlıklı yaşam biçimi davranışlarını belirlemek; sağlıklı bir yaşam tarzının benimsenmesindeki engellerin azaltılması ve sağlıklı yaşam biçimi davranışlarının geliştirilmesi çalışmaları açısından da önem taşımaktadır (Von Ah ve ark. 2004). Son yıllarda yapılan çalışmalarda sağlıklı yaşam biçimi davranışlarını geliştirilmesi açısından önemli bir dönem olan adölesan döneme yöne- lik çok daha fazla çalışmamanın gerekli olduğu belirtilmektedir (Dağdevire ve Şimşek 2013). Sağlıklı yaşam biçimi davranışları belirlenmesinin, sağlığı geliştirme davranışlarının belirlenmesinde ve bu amaca yönelik planlanacak programların etkinliğini değerlendirilmesinde kullanılabileceği belirtilmiştir (Bahar, Beser, Gordes, Ersin ve Kısal 2008). Literatürde Türk nüfusunun sağlıklı yaşam biçimi davranışlarını anlamak için çok daha fazla bilginin gerekli olduğu belirtilmektedir (Pınar, Çelik ve Bahçecik 2009).

Bireyin, ailenin ve toplumun sağlığın geliştirilmesi için sağlıklı yaşam biçimi davranışlarının arttırılmas1 gerekir. Bu nedenle adolesan döneminde ki öğrencilerin sağlık davranışlarının incelenmesi, ihtiyaç duydukları konularda desteklenmesi bireylerin sağlı̆̆ının geliştirilmesi için önemlidir. Bu araştırma, lise son s1nıf öğrencilerinin sağlıklı yaşam biçimi davranışlarının belirlenmesi amacıyla gerçekleştirilmiştir.

\section{YÖNTEM}

\section{Araştırmanın Amacı ve Tipi}

Sağlıklı yaşam biçimi davranışlarına ilişkin pek çok çalışma bulunmakla birlikte bu örneklemde Türkiye'de Sağlıklı Yaşam Biçimi Davranışları-II ölçeği ile yapılan az sayıda çalışmaya rastlanılmıştır. Bu araştırma, Sağlıklı yaşam biçimi davranışları ölçeği-II kullanılarak lise son sınıf öğrencilerinin sağlıklı yaşam biçimi davranışlarının belirlenmesi ve davranışları etkileyen etmenlerin incelenmesi amacıyla tanımlayıcı ve ilişki arayıcı türde gerçekleştirildi.

\section{Araştırmanın Evreni ve Örneklemi}

Araştırmanın evrenini, Marmara bölgesinin en büyük illerinden birindeki bir ortaöğretim kurumunda 10.04.2010-05.05.2010 tarihleri arasında eğitimöğrenim gören tüm son sinıf öğrencileri (200 öğrenci), örneklemini ise araştırmanın yapıldığı tarihlerde okulda olan ve araştırmanın amacı açıklandıktan sonra araştırmaya katılmayı gönüllü olarak kabul eden 160 öğrenci oluşturdu. Çalışmanın örneklemini adölesan dönemine daha yakın olduğu için lise son sınıf öğrencileri oluşturmaktadır. Ortaöğretim kurumu taşımalı 
eğitim veren, öğrenci mevcudu yüksek okullardan birisidir. Anketin yanıtlanma oranı: \%80 idi. Öğrencilerin yaş ortalamasının 17,44 $\pm 0,65$ (min:16-max:21) olduğu saptand1.

\section{Veri Toplama Araçları}

Verilerin toplanmasında literatür bilgileri doğrultusunda geliştirilen Bilgi Formu ve öğrencilerin sağlığı geliştirme davranışlarını belirlemek için Sağlıklı Yaşam Biçimi Davranışları Ölçeği-II kullanıldı.

Bilgi Formu: Bilgi Formu; öğrencilerin yaş, cinsiyet, yaşamlarının büyük bölümünü geçirdiği yer gibi bireysel özelliklerin yanı sıra kronik hastalık varlığı, sigara ve alkol kullanma durumu, çevresinde sağlık personeli bulunma gibi sağlık davranışlarını etkileyebilecek bilgilerin de yer aldiğı 11 sorudan oluştu.

Sağlıklı Yaşam Biçimi Davranışları Ölçeği SYBDÖII (Health Promotion Life Style Profile-II/ HPLP-II): Sağlıklı Yasam Biçimi Davranışları Ölçeği-SYBDÖ II, Walker, Sechrist ve Pender (1987) tarafindan geliştirilen Sağlıklı Yaşam Biçimi Ölçeği-SYBDÖ’nin, 1996 yılında tekrar çalışılarak gözden geçirilmiş versiyonudur (Walker, Kerr, Pender ve Sechrist 1990). SYBDÖ 48 maddelik olan ilk versiyonun geçerlik ve güvenirlik çalışması Esin (1997) tarafından yapılmıştır. SYBDÖII'nin geçerlik ve güvenirlik çalışması ise Bahar ve ark. (2008), Pınar, Çelik ve Bahçecik (2009) tarafından yapılmıştır. SYBDÖ-II' nin Türkçe geçerlilik ve güvenirlik çalışmasında cronbach alfa katsayısı Bahar ve ark. (2008)'nın çalışmasında 0.92, Pınar ve ark. (2009)'nın çalışmasında ise 0.70 olduğu saptanmış olup ölçeğin yüksek güvenirlik derecesine sahip olduğu belirtilmektedir. Bu çalışmada, Bahar ve ark. (2008) geçerlilik güvenirlik çalışması sonucu kazandırdığg 52 maddelik ölçek kullanılmıştır. Ölçeğin ilk versiyonunda yer alan kişilerarası destek alt faktörü, kişilerarası ilişkiler; egzersiz alt faktörü fiziksel aktivite; kendini gerçekleştirme alt faktörü ise manevi gelişim olarak yeniden adlandırılmıştır (Bahar ve ark. 2008; Pınar ve ark. 2009).

Ölçeğin derecelendirmesi hiçbir zaman (1), bazen (2), s1k sık (3), düzenli olarak (4) olmak üzere 4'lü likert şeklindedir. Ölçeğin sağlık sorumluluğu, kişilerarası ilişkiler, fiziksel aktivite, beslenme, stres yönetimi ve manevi gelişim olmak üzere altı alt boyutu bulunmaktadır (Bahar ve ark. 2008; Carlson 2000). Ölçeğin tamamı için en düşük puan 52, en yüksek puan 208'dir (Bahar ve ark. 2008). Bu araştırmada ölçeğin cronbach alfa katsayıs1 0,91 $(\mathrm{n}=160)$ olarak saptand1.

\section{Verilerin Değerlendirilmesi}

Elde edilen veriler, SPSS 11,5 for Windows paket programında değerlendirildi. Bireysel özellikler ve sağlıklı yaşam biçimi davranışlarını etkileyebilecek faktörler ile SYBDÖ-II ölçeği arasındaki farkın belirlenmesinde sayısal, yüzdelik dağılımın yanı sıra hem parametrik testler ( $\mathrm{t}$ testi, tek yönlü varyans analizi (ANOVA), Tukey HSD post-hoc önemlilik) hem de nonparametrik testler (Mann whitney-U ve Kruskal wallis) kullanıldı.

\section{Etik Konular}

Araştırmanın yapılabilmesi için ilin bağlı olduğu İl Milli Eğitim Müdürlüğü'nden yazılı izin alındı. Ortaöğretim kurumu müdürlüğüne ve öğrencilere araştırmanın amacı açıklandıktan sonra araştırmaya katılım için gönüllü/ istekli olan ve izin alınan öğrenciler oluşturdu.

\section{Araştırmanın Sınırlııkları}

Araştırma, araştırmacının ulaşabildiği bir okuldaki araştırmanın yapıldığı tarihte okulda bulunan öğrenciler ile yapılması araştırmanın sınırlılıklarındandır. Ayrıca ankete verilen yanıtlar, araştırmaya katılan öğrencilerin cevapları ile sınırlıdır.

\section{BULGULAR}

$\mathrm{Bu}$ araştırmadaki lise öğrencilerinin SYBDÖ-II' den $118.50 \pm 18.99$ puan aldığı saptand1. Öğrencilerin SYBDÖ-II'nin alt boyutlarından aldıkları yüksekten düşüğe puanlar sıralandığında en yüksek puanın manevi gelişim boyutundan (25.18 \pm 4.58$)$, en düşük puanın ise fiziksel aktivite $(14.81 \pm 4.33)$ boyutundan alındığı saptand1. (Tablo 1). 
Öğrencilerin sosyo-demografik özellikleri ile SYBDÖII'den aldıkları puanların karşılaştırılmasına Tablo 2'de yer verildi. Araştırma kapsamındaki erkek ve kız öğrencilerin SYBDÖ-II'den aldıkları puanlar karşılaştırıldı ğında anlamlı fark görülmedi $(\mathrm{p}>0.05)$. Ancak erkek öğrencilerin fiziksel aktivite davranışlarının kız öğrencilere göre $(\mathrm{p}<0.01)$, kız öğrencilerin sağlık sorumluluğu $(\mathrm{p}<0.05)$, beslenme $(\mathrm{p}<0.05)$ ve kişiler aras1 ilişki $(p<0.01)$ davranışlarının ise erkek öğrencilere göre daha olumlu olduğu saptandı.

Öğrencilerin ailelerinin en çok yaşadığı yere göre sağlıklı yaşam biçimi davranışları ölçeği toplam puanları karşılaştırıldığında, yaşamlarının büyük çoğunluğunu ilçede geçiren öğrencilerin kasabada/ köyde geçiren öğrencilere göre daha olumlu sağlık davranışları gösterdiği belirlendi $(\mathrm{p}<0.05)$. Ayrıca yaşamının büyük çoğunluğunu ilçede geçiren öğrencilerin sağlik sorumluluğu, beslenme, kişilerarası ilişkiler ve manevi gelişim alt boyutlarından daha fazla puan aldığg görüldü $(\mathrm{p}<0.05)$.
Tablo 1. Sağlıklı Yaşam Biçimi Davranışı Ölçeği ve Ölçek Alt Boyut Puanlarının Karşılaştırılması

\begin{tabular}{|l|c|c|c|}
\hline Alt Boyutlar & $\mathbf{X} \pm$ SD & $\begin{array}{c}\text { Alınan } \\
\text { Min-Max }\end{array}$ & $\begin{array}{c}\text { Alınabilecek } \\
\text { Min-Max }\end{array}$ \\
\hline $\begin{array}{l}\text { Sağlık } \\
\text { Sorumluluğu }\end{array}$ & $17.24 \pm 4.52$ & $9-32$ & $9-36$ \\
\hline $\begin{array}{l}\text { Fiziksel } \\
\text { Aktivite }\end{array}$ & $14.81 \pm 4.33$ & $8-32$ & $8-32$ \\
\hline Beslenme & $18.49 \pm 3.97$ & $9-31$ & $9-36$ \\
\hline $\begin{array}{l}\text { Kişilerarası } \\
\text { İlişkiler }\end{array}$ & $24.09 \pm 4.39$ & $9-35$ & $9-36$ \\
\hline $\begin{array}{l}\text { Stres } \\
\text { Yönetimi }\end{array}$ & $18.69 \pm 3.89$ & $8-29$ & $8-32$ \\
\hline $\begin{array}{l}\text { Manevi } \\
\text { Gelişim }\end{array}$ & $25.18 \pm 4.58$ & $10-36$ & $9-36$ \\
\hline Toplam & $118.50 \pm 18.99$ & $53-195$ & $52-208$ \\
\hline
\end{tabular}

Aile/ akrabaların oluşturduğu geniş ailede yaşayan öğrencilerin boşanma/ ayrılık/ ölüm nedeniyle parçalanmış ailede yaşayan öğrencilere göre sağlıklı yaşam biçimi davranışlarının daha az olduğu saptandı

Tablo 2. Bireysel Özelliklerin Sağlıklı Yaşam Biçimi Davranışı Ölçeği Alt Boyutları ile Karşılaştırılması

\begin{tabular}{|c|c|c|c|c|c|c|c|c|c|}
\hline & & \multirow{2}{*}{$\begin{array}{c}\text { Sağlık } \\
\text { Sorumluluğu }\end{array}$} & \multirow{2}{*}{$\begin{array}{l}\text { Fiziksel } \\
\text { Aktivite }\end{array}$} & \multirow{2}{*}{ Beslenme } & \multirow{2}{*}{$\begin{array}{l}\text { Kişilerarası } \\
\text { İlişkiler }\end{array}$} & \multirow{2}{*}{$\begin{array}{c}\text { Stres } \\
\text { Yönetimi }\end{array}$} & \multirow{2}{*}{$\begin{array}{l}\text { Manevi } \\
\text { Gelişim }\end{array}$} & \multirow{2}{*}{ Toplam } \\
\hline & & & & & & & & & \\
\hline & & n (\%) & $\mathrm{X} \pm \mathrm{SD}$ & $\mathbf{X} \pm \mathrm{SD}$ & $\mathrm{X} \pm \mathrm{SD}$ & $\mathbf{X} \pm \mathbf{S D}$ & $\mathbf{X} \pm \mathbf{S D}$ & $\mathbf{X} \pm \mathrm{SD}$ & $\mathbf{X} \pm$ SD \\
\hline \multirow{2}{*}{ Yaş } & 17 ve altı & $97(60.6)$ & $17.25 \pm 4.22$ & $14.56 \pm 4.36$ & $18.52 \pm 3.84$ & $24.32 \pm 4.00$ & $18.74 \pm 3.73$ & $25.16 \pm 4.54$ & $118.56 \pm 18.01$ \\
\hline & 18 ve üstü & $63(39.4)$ & $17.24 \pm 4.98$ & $15.19 \pm 4.29$ & $18.43 \pm 4.19$ & $23.75 \pm 4.95$ & $18.62 \pm 4.15$ & $25.19 \pm 4.68$ & $118.41 \pm 20.55$ \\
\hline \multicolumn{3}{|r|}{$t$ testi } & .013 & -.903 & .151 & .806 & .195 & -.034 & .047 \\
\hline \multirow{2}{*}{ Cinsiyet } & Erkek & $72(45.0)$ & $16.40 \pm 4.33$ & $16.12 \pm 4.69$ & $17.79 \pm 3.92$ & $22.74 \pm 4.20$ & $18.46 \pm 4.19$ & $24.90 \pm 4.67$ & $116.42 \pm 19.43$ \\
\hline & $\mathrm{K} 1 \mathrm{z}$ & $88(55.0)$ & $17.93 \pm 4.58$ & $13.73 \pm 3.71$ & $19.06 \pm 3.94$ & $25.20 \pm 4.25$ & $18.89 \pm 3.63$ & $25.40 \pm 4.52$ & $120.20 \pm 18.55$ \\
\hline \multicolumn{3}{|r|}{$\mathrm{t}$ testi } & $-2.152 *$ & $3.612 * *$ & $-2.025 *$ & $-3.673 * *$ & -.691 & -.679 & -1.258 \\
\hline \multirow{3}{*}{$\begin{array}{l}\text { Yaşadığı } \\
\text { Yer }\end{array}$} & Köy-kasaba & 33 (20.6) & $15.64 \pm 4.41$ & $14.61 \pm 4.81$ & $16.76 \pm 3.65$ & $22.88 \pm 4.27$ & $17.85 \pm 4.00$ & $23.67 \pm 3.29$ & $111.42 \pm 17.87$ \\
\hline & İlçe & $102(63.8)$ & $17.50 \pm 4.13$ & $15.00 \pm 4.47$ & $19.23 \pm 3.75$ & $24.14 \pm 4.13$ & $19.13 \pm 3.72$ & $25.91 \pm 4.34$ & $120.91 \pm 17.61$ \\
\hline & Şehir & $25(15.6)$ & $18.32 \pm 5.71$ & $14.28 \pm 2.99$ & $17.72 \pm 4.49$ & $25.52 \pm 5.24$ & $18.04 \pm 4.28$ & $24.12 \pm 6.23$ & $118.00 \pm 23.73$ \\
\hline \multicolumn{3}{|c|}{ Kruskal wallis testi } & $6.603 *$ & .732 & $8.542 *$ & $7.160 *$ & 3.476 & $6.036 *$ & $6.473 *$ \\
\hline \multirow{3}{*}{$\begin{array}{l}\text { Aile } \\
\text { Türü }\end{array}$} & Çekirdek & $132(82.5)$ & $17.47 \pm 4.66$ & $15.04 \pm 4.39$ & $18.68 \pm 4.05$ & $24.16 \pm 4.53$ & $18.76 \pm 3.76$ & $25.37 \pm 4.64$ & $119.50 \pm 19.05$ \\
\hline & Geniş & 19 (11.9) & $15.10 \pm 3.51$ & $12.53 \pm 3.53$ & $16.84 \pm 3.45$ & $23.42 \pm 4.06$ & $17.421 \pm 4.11$ & $24.42 \pm 4.46$ & $109.74 \pm 18.60$ \\
\hline & Parçalanmış & $(5.6)$ & $18.33 \pm 3.16$ & $16.11 \pm 3.76$ & $19.11 \pm 3.180$ & $24.55 \pm 3.04$ & $20.33 \pm 4.90$ & $23.89 \pm 4.07$ & $122.33 \pm 14.98$ \\
\hline \multicolumn{3}{|c|}{ Kruskal wallis testi } & 6.998* & $6.823 *$ & 4.033 & .839 & 3.212 & 1.708 & 7.054* \\
\hline \multirow{3}{*}{$\begin{array}{l}\text { Ailenin } \\
\text { Gelir } \\
\text { Durumu }\end{array}$} & Gelir $<$ Gider & $23 \quad(14.4)$ & $16.04 \pm 3.85$ & $13.65 \pm 2.87$ & $16.65 \pm 3.57$ & $23.26 \pm 4.73$ & $16.83 \pm 3.99$ & $23.17 \pm 4.30$ & $109.61 \pm 18.61$ \\
\hline & Gelir $=$ Gider & $108(67.5)$ & $17.40 \pm 4.65$ & $14.79 \pm 4.27$ & $18.80 \pm 3.95$ & $24.10 \pm 4.41$ & $18.92 \pm 3.71$ & $25.30 \pm 4.41$ & $119.30 \pm 18.78$ \\
\hline & Gelir $>$ Gider & $29(18.1)$ & $17.62 \pm 4.51$ & $15.79 \pm 5.31$ & $18.76 \pm 4.08$ & $24.72 \pm 4.07$ & $19.34 \pm 4.16$ & $26.31 \pm 5.08$ & $122.55 \pm 18.50$ \\
\hline \multicolumn{3}{|c|}{ Kruskal wallis testi } & 1.496 & 2.311 & 6.573* & 1.351 & 5.042 & $6.211 *$ & 7.402* \\
\hline
\end{tabular}

*anlamlılık. 05 **anlamlılık.001 
$(p<0.05)$. Ayrıca geniş ailede yaşayan öğrencilerin sağlık sorumluluğu ve fiziksel aktivite alt boyutlarından da düşük puan aldıkları belirlendi $(\mathrm{p}<0.05)$. Aynı zamanda ailelerinin gelirleri giderinden fazla olan öğrencilerin SYBDÖ-II'den, gelirleri giderinden az olan öğrencilere göre daha fazla puan ald1ğ1 yani daha olumlu davranış gösterdikleri belirlendi $(p<0.05)$.

Sağlıklı yaşam biçimi davranışlarını etkileyebileceği düşünülen faktörlerden ögrrencilerin kronik hastalığa sahip olma, sigara ve alkol kullanma durumu ile sağlıklı yaşam biçim davranışları arasında anlam1 fark saptanmadı ( $p>0.05$ ). Ancak çevrelerinde/tanıdıkları sağlık personeli olan öğrencilerin sağlıklı yaşam biçimi davranışlarının daha olumlu olduğu görüldü $(\mathrm{p}<0.05)($ Tablo 3$)$

\section{TARTIŞMA}

Bu araştırmadaki lise öğrencilerinin SYBDÖ-II'den $118,50 \pm 18,99$ puan aldığı, sağlık davranışlarının orta düzeyde olduğu saptandı. Bu araştırmadaki SYBDÖII puanın Hulme ve ark. (2003)'nın çalışmasındaki puandan düşük olduğu saptandı. Benzer örneklemde SYBDÖ-II ile yapılan az sayıda çalışmaya rastlanılmış olup SYBDÖ’nin ilk versiyonu ile benzer yapıdadır. Lise öğrencilerinin sağlık davranışlarının orta düzeyde olduğu bulgusu SYBDÖ kullanılarak Türkiye'de lise öğrencileri yapılan diğer çalışma sonuçlarına (Ergün ve Erol 2007; Geçkil ve Yıldız 2006) benzer bulundu. Ancak bu bulgu üniversite öğrencileri (Karadeniz, Uçum, Dedeli ve Karaağaç 2008) ve sağlıkla ilgili eğitim gören öğrencilerden (Aksungur, Göktaş, Önder ve Cankul 2011; Cihangiroğlu ve Deveci 2011) düşük

Tablo 3. Sağlıklı Yaşam Biçimi Davranışı Ölçeğini Etkileyebilecek Faktörlerin İncelenmesi

\begin{tabular}{|c|c|c|c|c|c|c|c|c|c|}
\hline & & & $\begin{array}{c}\text { Sağlık } \\
\text { Sorumluluğu }\end{array}$ & $\begin{array}{l}\text { Fiziksel } \\
\text { Aktivite }\end{array}$ & Beslenme & $\begin{array}{l}\text { Kișilerarası } \\
\text { İlişkiler }\end{array}$ & $\begin{array}{c}\text { Stres } \\
\text { Yönetimi }\end{array}$ & $\begin{array}{l}\text { Manevi } \\
\text { Gelişim }\end{array}$ & Toplam \\
\hline & & n (\%) & $\mathbf{X} \pm \mathbf{S D}$ & $\mathrm{X} \pm \mathrm{SD}$ & $\mathbf{X} \pm \mathbf{S D}$ & $\mathbf{X} \pm$ SD & $\mathbf{X} \pm$ SD & $\mathbf{X} \pm \mathbf{S D}$ & $\mathbf{X} \pm$ SD \\
\hline \multirow{2}{*}{$\begin{array}{l}\text { Kronik } \\
\text { Hastalık }\end{array}$} & Evet & $7 \quad(4.4)$ & $18.57 \pm 6.95$ & $15.57 \pm 4.24$ & $18.00 \pm 4.32$ & $25.28 \pm 6.13$ & $17.57 \pm 5.53$ & $23.43 \pm 7.30$ & $118.43 \pm 28.91$ \\
\hline & Hayır & 153 (95.6) & $17.18 \pm 4.40$ & $14.77 \pm 4.35$ & $18.51 \pm 3.97$ & $24.04 \pm 4.32$ & $18.74 \pm 3.81$ & $25.25 \pm 4.44$ & $118.50 \pm 18.55$ \\
\hline \multicolumn{3}{|c|}{ Mann Whitney-U } & 489.500 & 491.500 & 520.500 & 393.500 & 522.500 & 512.000 & 466.500 \\
\hline \multirow{2}{*}{$\begin{array}{l}\text { Sigara } \\
\text { İçme } \\
\text { Durumu }\end{array}$} & Evet & $23(14.4)$ & $15.65 \pm 4.34$ & $14.30 \pm 3.17$ & $17.22 \pm 3.98$ & $22.39 \pm 4.31$ & $19.13 \pm 4.15$ & $24.61 \pm 4.86$ & $113.30 \pm 17.15$ \\
\hline & Hayır & $137(85.6)$ & $17.51 \pm 4.51$ & $14.89 \pm 4.50$ & $18.70 \pm 3.94$ & $24.38 \pm 4.35$ & $18.62 \pm 3.86$ & $25.27 \pm 4.55$ & $119.37 \pm 19.20$ \\
\hline \multicolumn{3}{|r|}{ t testi } & -1.838 & -.599 & -1.667 & $-2.028 *$ & .581 & -.639 & -1.423 \\
\hline \multirow{3}{*}{$\begin{array}{l}\text { Sigara } \\
\text { Adeti }\end{array}$} & 1-10 adet/gün & $17(73.9)$ & $15.53 \pm 4.60$ & $14.29 \pm 3.35$ & $17.12 \pm 4.14$ & $21.65 \pm 4.24$ & $18.35 \pm 3.18$ & $23.65 \pm 4.83$ & $110.59 \pm 16.87$ \\
\hline & $11-20$ adet/gün & $4 \quad(17.4)$ & $15.25 \pm 3.86$ & $14.50 \pm 3.70$ & $16.75 \pm 2.36$ & $23.50 \pm 4.93$ & $19.00 \pm 5.60$ & $26.50 \pm 4.79$ & $115.50 \pm 17.39$ \\
\hline & 20 üstü/gün & $2(8.7)$ & $17.50 \pm 4.95$ & $14.00 \pm 0.00$ & $19.00 \pm 7.07$ & $26.50 \pm .71$ & $26.00 \pm 4.24$ & $29.00 \pm 2.83$ & $132.00 \pm 12.72$ \\
\hline \multicolumn{10}{|c|}{ Karşı1laştırma yapılamadı } \\
\hline \multirow{2}{*}{ Alkol } & Evet & $40(25.0)$ & $16.47 \pm 4.00$ & $16.20 \pm 3.88$ & $18.25 \pm 4.22$ & $22.85 \pm 4.03$ & $19.05 \pm 4.12$ & $24.47 \pm 4.37$ & $117.30 \pm 17.48$ \\
\hline & Hayır & $120(75.0)$ & $17.50 \pm 4.67$ & $14.34 \pm 4.39$ & $18.57 \pm 3.90$ & $24.51 \pm 4.44$ & $18.57 \pm 3.82$ & $25.41 \pm 4.64$ & $118.90 \pm 19.51$ \\
\hline \multicolumn{3}{|r|}{ t testi } & -1.244 & $2.383 *$ & -.436 & -2.090 & .668 & -1.116 & -.460 \\
\hline \multirow{2}{*}{$\begin{array}{l}\text { Çevresinde } \\
\text { Sağlık } \\
\text { Personeli } \\
\text { Bulunma }\end{array}$} & Evet & $85(53.1)$ & $17.81 \pm 4.43$ & $14.89 \pm 3.89$ & $18.75 \pm 4.00$ & $24.70 \pm 4.30$ & $19.30 \pm 3.57$ & $25.95 \pm 4.07$ & $121.42 \pm 17.34$ \\
\hline & Hayır & $75(46.9)$ & $16.60 \pm 4.57$ & $14.71 \pm 4.81$ & $18.19 \pm 3.94$ & $23.40 \pm 4.42$ & $18.00 \pm 4.14$ & $24.29 \pm 4.98$ & $115.19 \pm 20.30$ \\
\hline \multicolumn{3}{|r|}{ t testi } & 1.701 & .269 & .900 & 1.892 & $2.143 *$ & $2.317 *$ & 2.095* \\
\hline \multirow{2}{*}{$\begin{array}{l}\text { Yakınlık } \\
\text { Derecesi }\end{array}$} & 1.derece & $52(61.2)$ & $17.92 \pm 4.12$ & $14.61 \pm 3.61$ & $18.73 \pm 4.01$ & $24.48 \pm 4.06$ & $19.10 \pm 3.48$ & $25.69 \pm 3.63$ & $120.54 \pm 15.68$ \\
\hline & Diğer & $33(38.8)$ & $17.64 \pm 4.93$ & $15.33 \pm 4.31$ & $18.70 \pm 4.04$ & $25.06 \pm 4.70$ & $19.64 \pm 3.74$ & $26.36 \pm 4.70$ & $122.82 \pm 19.85$ \\
\hline \multicolumn{3}{|r|}{ t testi } & .289 & -.0827 & -.064 & -.0603 & -.677 & -.740 & -.588 \\
\hline
\end{tabular}

*anlamlılık. 05 
olduğu belirlendi. Nitekim yetişkin olmanın, üniversitede eğitim almanın, özellikle sağlıkla ilgili okullarda eğitim almanın sağlıklı yaşam biçimi davranışlarını arttırması beklenen bir sonuçtur. Ancak bu araştırmada lise öğrencilerinin sağlıklı yaşam biçimi davranışının orta düzeyde olmasının diğer bir nedeni olarak ilk ve ortaögretim müfredat programlarında sağlığg geliştirme konularına daha az yer verilmesinden kaynaklanabileceği de düşünülmektedir.

SYBDÖ-II'nin alt boyutlarına ilişkin karşılaştırmalarda ise, en yüksek puanın manevi gelişim boyutundan, en düşük puanın ise fiziksel aktivite alt boyutundan alındığı belirlendi. Bu araştırmada saptanan en yüksek puanın manevi gelişim boyutundan alınması SYBDÖII ile yapılan diğer çalışma bulgularına paralellik göstermektedir (Dağdevire ve Şimşek 2013; Hulme ve ark. 2003; Irmak-Vural ve Bakır 2015). Ayrıca SYBDÖ'de kendini gerçekleştirme boyutu; SYBDÖII ölçeğinde manevi gelişim boyutu olarak adlandırıldığından en yüksek puanın kendini gerçekleştirme boyutundan alındığı öğrenciler ile yapılan diğer çalışma bulgularına da benzer olduğu saptandı (Aksungur ve ark. 2011; Cihangiroğlu ve Deveci 2011). Fakat yapılan benzer başka bir araştırma da bu verilen aksine hemşirelik öğrencilerinin SYBDÖ-II alt boyutlarından aldıkları puan ortalamalarına bakıldığında en yüksek puanı sağlık sorumluluğu aldığı görüldü (Özyazıcığlu, Kılıç, Erdem, Yavuz ve Afacan 2011). Ölçekten en düşük puanın fiziksel aktivite boyutundan alınması, Türkiye'de (Aksungur ve ark. 2011; Geçkil ve Yıldız 2006) ve diğer ülkelerde (Hulme ve ark. 2003) yap1lan çalışma bulgularına da benzer bulundu.

Araştırma kapsamındaki erkek ve kız öğrencilerin SYBDÖ-II' den aldıkları toplam puanlar karşılaştırıldığında anlamlı fark saptanmadı. Ancak bu çalışmada ki lise öğrencilerinden kızların fiziksel aktivite davranışları dışında sağlık sorumluluğu, beslenme ve kişiler arası ilişki puanlarının erkek öğrencilere göre daha olumlu sağlıkla davranışlarına sahip oldukları saptand1 (Chen, Shiao ve Gau 2007; Hulme ve ark. 2003; Özyazıcıoğlu ve ark. 2011; Karadeniz ve ark. 2008). Bununla birlikte cinsiyet ile SYBD arasında fark saptana- mayan çalışmalar (Cihangiroğlu ve Deveci 2011; Ünalan, Şenol, Öztürk ve Erkorkmaz 2007) olduğu gibi aksine erkek öğrencilerin SYBD ortalamalarının yüksek olduğu çalışmalar da bulunmaktadır (Dağdevire ve Şimşek 2013; Geçkil ve Yıldız 2006). Irmak-Vural ve Bakır (2015)'ın yaptığı araştırmada kız öğrencilerin sağlık sorumluluğu, beslenme, stres yönetimi alt grubu puan ortancasının erkek öğrencilere göre istatistiksel olarak anlamlı düzeyde yüksek olduğu saptanması, yapılan bu araştırmada da kız öğrencilerin sağlık sorumluluğu ve beslenme ve kişilerarası ilişki davranışlarının daha olumlu olmasının Türk toplumu tarafından kadına atfedilen rollerden kaynaklandığı düşünülmektedir. Amerika Birleşik Devletleri'nde yapılan Hulme ve ark. (2003) çalışmasında erkeklerin manevi gelişim davranışlarına daha yüksek katılım göstermelerinin nedeninin onların ve ailelerinin yaşamlarında gelişimi aradıklarını bu davranışlarının da önleyici tutumlarının yansıması olduğunu belirtmişlerdir.

Sağlıkla ilgili davranışlar ele alındığında sosyal ve ekonomik etkenlerin kişisel davranışlarda önemli bir rol oynadığı bu açıdan önemle üzerinde durularak değerlendirme yapılması gerektiği belirtilmektedir (Koçoğlu ve Akın 2009; Ulla-Dı'Ez ve Pe' Rez-Fortıs 2009; Ünalan ve ark. 2007). Bu doğrultuda yaşamının büyük çoğunluğunu ilçede yaşayan öğrencilerin kasabada/ köyde yaşayan öğrencilere göre daha olumlu sağlık davranışları gösterdiği belirlendi. Benzer şekilde Ulla-Dı'Ez ve Pe'-Rez-Fortıs (2009)'ın çalışmasında da orta-yüksek sosyoekonomik düzeydeki öğrencilerde daha sağlıklı yaşam biçimi davranışları gözlendi. Bu bulgunun kasabada/köyde yaşayan öğrencilerin hem sağlıklı yaşam biçimi davranışları hakkındaki bilgi eksikliğinden hem de sosyo-ekonomik faktörlerden kaynaklanabileceği düşünülmektedir.

$\mathrm{Bu}$ araştırmanın ilgi çekici bulgularından birisi de geniş ailede yaşadığını ifade eden öğrencilerin boşanma/ ayrılık/ ölüm nedeniyle parçalanmış ailede yaşadığını ifade eden öğrencilere göre sağlıklı yaşam biçim davranışlarının daha olumsuz olduğu bulgusudur. Bu bulgu Chen ve ark. (2007)'nın aile yapısının sağlıkla ilgili davranışlarını etkileyen önemli bir değişken olduğu ve 
her iki ebeveyn ile yaşayan adölesanların tek bir ebeveynle yaşayan adölesanlara göre daha sağlıklı davranış gösterdiği çalışma bulgularına benzerlik göstermemiştir.

$\mathrm{Bu}$ araştırmadan elde edilen sonuçlar doğrultusunda ailelerin gelir durumu arttıkça öğrencilerin sağlıklı yaşam biçimi davranışlarının olumlu yönde arttığı belirlenmiştir. Konu ile ilgili olarak yapılan çalışmalarda ailenin gelir durumu iyi olanların sağlıklı yaşam biçim davranışlarını daha fazla benimsedikleri bildirilmiştir (Cihangiroğlu ve Deveci 2011; Esin 1997; Karadeniz ve ark. 2008; Ulla-Di'Ez ve Pe' Rez-Fortıs 2009). Sayan, Tan, Uğurlu ve Çevirme (2001) lise öğrencilerinin sosyoekonomik durumunun sağlık davranışlarını olumlu etkileyen, olumlu kendilik algısını etkilediğini belirtmişlerdir.

Lise son sınıf öğrencilerinin kronik hastalığa sahip olma durumları ile sağlık davranışları arasında anlam1 farklılığın olmadığı belirlenen bu çalışma Cihangiroğlu ve Deveci (2011)'nin çalışma bulgusu ile benzerlik göstermiştir. Farklılığın saptanamamasının nedenin, bu çalışmadaki öğrencilerin yaşlarının genç olması aynı zamanda kronik hastalığa sahip olan öğrencinin az sayıda olmasından kaynaklandığını düşünmekteyiz.

Olumsuz sağlıklı yaşam biçimi davranışlarının geliştirme açısından risk grubu olan adölesan dönemdeki lise öğrencilerinin sigara içme oranın \% 14,4 olarak saptandığı bu çalışmanın, yapılan benzer çalışmalardaki orana (Geçkil ve Yıldız 2006; Güler, Güler, Ulusoy ve Bekar 2009) yakın olduğu saptandı. Ayrıca sigara içen öğrencilerin içmeyen öğrencilere göre SYBDÖ ölçeği puan ortalamalarının daha düşük bulunduğu ancak istatistiksel olarak anlamlı olmadığ görüldü. Benzer şekilde öğrencilerin SYBDÖ puanları ile sigara kullanımları arasında anlamlı fark bulunmayan çalışmalara da rastlanmıştır (Ünalan ve ark. 2007). Sigara içen öğrencilerin, sigara içmeyenlere göre SYBDÖ'den düşük puan alması benzer çalışmalarla desteklenmektedir (Cihangiroğlu ve Deveci 2011). Ayrıca bir diğer olumsuz sağlık davranışı olan öğrencilerin alkol kullanıp kullanmama durumlarının SYBDÖ puanını etkilemediğinin saptanması, diğer benzer çalışma bulguları ile benzerlik göstermektedir (Karadeniz ve ark. 2008). Nitekim sigara ve alkol kullanımının olumsuz bir sağlıklı yaşam biçimi davranışı olduğu bilinen bir gerçektir.

Literatürde adölesanın sağlıklı davranışlar kazanması ve sürdürmesinin, ailesel temelli olmakla birlikte, arkadaş ve çevresel boyutlarının olduğu da belirtilmektedir (Sayan ve ark. 2001). Bu bağlamda sağlık çal1şanı yakını/tanıdığı olanların daha olumlu sağlıklı yaşam biçimi sergiledikleri bu çalışmanın sonucu diğer çalışmalarla paralellik göstermektedir (Aksungur ve ark. 2011).

\section{SONUÇ VE ÖNERILER}

$\mathrm{Bu}$ çalışmadaki lise son sınıf öğrencilerinin sağlık11 yaşam biçimi davranışlarının orta düzeyde olduğu, özellikle fiziksel aktivite ve sağlık sorumluluğu alt boyutlarından düşük puan alındığı belirlenmiştir. $\mathrm{Bu}$ doğrultuda lise öğrencilerinin ders müfredatlarında sağlığg geliştirmeye yönelik konulara yer verilmesi önerilmektedir. Ayrıca bu çalışmada yaşamlarının büyük çoğunluğunu ilçede geçiren öğrencilerin kasabada/ köyde geçiren öğrencilere göre daha olumlu sağlık davranışları gösterdiği, çevrelerinde/ tanıdıkları sağlık personeli olan öğrencilerin sağlıklı yaşam biçimi davranışlarının daha olumlu olduğu farklılığın bulunması çalışmanın önemli bulgularındandır. Çalışma sonuçlarına göre lise son sınıf öğrencilerine sağlıklı yaşam biçimi davranışlarına yönelik farkındalık kazandırılmasında eğitim programlarının önemli olabileceğinin altı çizilmektedir. Bu bağlamda düzenlenecek sigara, alkol ve bağımlılık yapan maddeleri bırakma, fiziksel aktiviteyi arttırma, beslenme, öfke kontrolü, sosyal ve psikolojik destek vb. konularda grup veya akran eğitim programlarının hazırlanmasında öğrencilerin bireysel özellikleri dikkate alınmasının yararlı olacağı düşünülmektedir. Aynı zamanda eğitim programlarının uygulamaya geçirilerek ögrencilerde sağlıklı yaşam biçimi davranışlarının kazandırılmasına yardımcı olup olmadığı düzenli aralıklarla değerlendirilmelidir. 


\section{Lise Son Sını Öğrencileri Sağlıklı Yaşam Biçimi Davranışlarına Sahipler mi?}

Bu araştırma sonuçlarının özellikle sağ 1 ğı geliştirmek için düzenlenecek eğitim programlarına rehber olabileceği düşünülmektedir. Aynı zamanda lise öğrencilerinin sağlıklı yaşam biçimi davranışları ile ilgili yapılacak çalışmalar için veri oluşturmaktadır. Bu bağlamda Sağlıklı Yaşam Biçimi Davranışları Ölçeği -II ile daha farklı örneklemlerde çalışma yapılması önerilmektedir.

\section{KAYNAKLAR}

Aksungur, A., Göktaş, B., Önder, Ö. R., Cankul, İ. H. (2011). Öğrencilerin sağlıklı yaşam davranışlarının değerlendirilmesi. Ankara Üniversitesi Sağllk Hizmetleri Dergisi, 10(1): 1-12.

Alıcı, S. A., Sarıkaya, Ö. (2009). Sağlık davranışlarının geliştirilmesinde yaşantılayarak öğrenme uygulaması. Dokuz Eylül Üniversitesi Hemşirelik Yüksekokulu Dergisi, 2(3): 95-101.

Bahar, Z., Beser, A., Gordes, N., Ersin, F., Kıssal, A. (2008). Sağlıklı Yaşam Biçimi Davranışları Ölçeği II' nin geçerlik ve güvenirlik çalışması. Cumhuriyet Üniversitesi Hemşirelik Yüksekokulu Dergisi, 12(1): 1-13.

Carlson, E. D. (2000). A case study in translation methodology using The Health-Promotion Lifestyle Profile-II. Public Health Nursing, 17(1): 61-70.

Chen, M. Y., Shiao, Y. C., Gau, Y. M. (2007). Comparison of adolescent health-related behavior in different family structures. Journal of Nursing Research, 15(1): 1-10.

Cihangiroğlu, Z., Deveci, S. E. (2011). Fırat Üniversitesi Elazı̆̆ Sağlık Yüksekokulu öğrencilerinin sağlıklı yaşam biçimi davranışları ve etkileyen faktörler. Firat Tip Dergisi, 16(2): 78-83.

Dağdevire, Z., Şimşek, Z. (2013). Şanlıurfa il merkezindeki lise öğrencilerinin sağlığ 1 geliştirme davranışları ve ilişkili faktörler. TSK Koruyucu Hekim Bülteni, 12(2): 135-142.

Dünya Sağl1k Örgütü (DSÖ) Kütüphanesi Kataloğu (2011). Dünya Sağlık Örgütü bulaşıcı olmayan hastalıklara ilişkin küresel durum raporu 2010, http://beslenme.gov.tr/content/files/home/kuresel_durum_raporu.pdf (21.01.2015)

Ergün, A., Erol, S. (2007). Lise öğrencilerinin sağlıklı yaşam biçimi davranışları. Hemşirelik Forumu, Ocak-Şubat/Mart-Nisan: 46-51.

Esin, N. (1997). Endüstriyel alanda çalışan işçilerin sağlık davranışlarının saptanması ve geliştirilmesi. Yayınlanmamış Doktora Tezi, İstanbul Üniversitesi Sağlık Bilimleri Enstitüsü, İstanbul.
Geçkil, E., Yıldız, S. (2006). Adolescent health behaviors and problems. Journal of Hacettepe University School of Nursing, 13(1): 2634.

Güler, N., Güler, G., Ulusoy, H., Bekar, M. (2009). Lise öğrencileri arasında sigara, alkol kullanımı ve intihar düşüncesi sıklığı. Cumhuriyet Tip Dergisi, 31: 340-345.

Hulme, P. A. ve ark. (2003). Health-promoting lifestyle behaviors of Spanish-speaking Hispanic adults. Journal of Transcultural Nursing, 14(3): 244-254.

Irmak-Vural, P., Bakır, N. (2015). Meslek yüksekokulu öğrencilerinin sağlıklı yaşam biçimi davranışları ve etkileyen faktörler. Acıbadem Üniversitesi Sağllk Bilimleri Dergisi, 6(1): 36-42.

Karadeniz, G., Uçum, E. Y., Dedeli, Ö., Karaağaç, Ö. (2008). Üniversite öğrencilerinin sağlıklı yaşam biçimi davranışları. TSK Koruyucu Hekimlik Bülteni, 7(6): 497-502.

Koçoğlu, D., Akın, B. (2009). Sosyo-ekonomik eşitsizliklerin sağlıklı yaşam biçimi davranışları ve yaşam kalitesi ile ilişkisi. Dokuz Eylül Hemşirelik Yüksekokulu Elektronik Dergisi, 2(4): 145-154.

Özyazıcıŏlu, N., Kılıç, M., Erdem, N., Yavuz, C., Afacan, S. (2011). Hemşirelik öğrencilerinin sağlıklı yaşam biçimi davranışlarının belirlenmesi. Uluslararası Insan Bilimleri Dergisi, 8(2): 277-332.

Pınar, R., Çelik, R., Bahçecik, N. (2009). Reliability and construct validity of the Health-Promoting Lifestyle Profile II in an adult Turkish population. Nursing Research, 58(3): 184-193.

Sayan, A., Tan, M., Uğurlu, N., Çevirme, H. (2001). Üç farklı sosyoekonomik düzeydeki lise son sınıf öğrencilerinde olumlu sağlık davranışları, olumlu kendilik algısı ilişkisi. Atatürk Üniversitesi Hemşirelik Yüksekokulu Dergisi, 4(2): 2-31.

Ulla Di'Ez, S. M., Pe' Rez-Fortıs, A. (2009). Socio-Demographic predictors of health behaviors in Mexican college students. Health Promotion International, 25(1): 85-93.

Ünalan, D., Şenol, V., Öztürk, A., Erkorkmaz, Ü. (2007). Meslek yüksekokullarının sağlık ve sosyal programlarında öğrenim gören öğrencilerin sağlıklı yaşam biçimi davranışları ve öz-bakım gücü düzeyleri arasındaki ilişkinin incelenmesi. İönü Üniversitesi Tıp Fakültesi Dergisi, 14(2): 101-109.

Von Ah, D., Ebert, S., Ngamvitroj, A., Park, N., Kang, D. H. (2004). Predictors of health behaviours in college students. Journal of Advanced Nursing, 48(5): 463-474.

Walker, S. N., Kerr, M. J., Pender, N. J., Sechrist, K. R. (1990). A Spanish language version of the Health Promoting Lifestyle Profile. Nursing Research, 39(5): 268-273. 